\title{
Romantic Relationships, Adolescence and HIV: Love as an Element of Vulnerability
}

\author{
Adriana de Aguiar ${ }^{1}$ \\ Universidade Federal de Santa \\ Catarina, Florianópolis-SC, Brazil
}

\author{
Brigido Vizeu Camargo \\ Universidade Federal de Santa \\ Catarina, Florianópolis-SC, Brazil
}

\begin{abstract}
This study investigated the relation between love and different romantic relationships with variable vulnerability to HIV, such as sexual behavior and risk perception. Sternberg's Triangular Love Scale and a structured questionnaire were used to ask 301 high school students about: romantic relationships, sexual behavior and risk perceptions. It was identified that the adolescents underestimate their own risk of contagion when they compare themselves with other individuals and also when they consider past and future possible HIV contagion. Love does not appear to be directly associated with the selfperception of risk, however, in conjunction with dating, it is a complicating factor for protected sex and was also related to the underestimation of risk of the partner. It was observed that stable relationships and love increase the students' vulnerability to acquire HIV, because of the association of these with trust in the partner and the justification of risky practices, such as the non-use of condoms.
\end{abstract}

Keywords: love, vulnerability, HIV, adolescence

\section{Relações Amorosas, Adolescência e HIV: O Amor Como Elemento de Vulnerabilidade}

\begin{abstract}
Resumo: Este estudo investigou a relação do amor e de diferentes relacionamentos amorosos com variáveis de vulnerabilidade ao HIV, como comportamento sexual e percepção de risco. Utilizou-se a Escala Triangular do Amor de Sternberg e um questionário estruturado para inquirir 301 estudantes de ensino médio sobre relações amorosas, comportamento sexual e percepção de risco frente ao HIV. Identificou-se que os adolescentes subestimam o próprio risco de contágio quando se comparam a outros indivíduos e quando consideram a possibilidade de contágio passado e futuro. $\mathrm{O}$ amor não apareceu diretamente associado à autopercepção de risco, porém, juntamente com o namoro, apresentou-se como complicador do sexo protegido e relacionado à subestimação do risco do parceiro. Observou-se que relacionamentos estáveis e o amor constituem elementos que aumentam a vulnerabilidade ao HIV, por terem relação com a confiança no parceiro e por justificarem práticas arriscadas, como o não uso do preservativo.
\end{abstract}

Palavras-chave: amor, vulnerabilidade, HIV, adolescência

\section{Las Relaciones Románticas, la Adolescencia y el VIH: El Amor Como un Elemento de Vulnerabilidad}

\begin{abstract}
Resumen: Este estudio investigó la relación del amor y relaciones románticas con variables de la vulnerabilidad al VIH, tales como comportamiento sexual y percepción de riesgo. Se utilizó la Escala Triangular del Amor de Sternberg y un cuestionario estructurado en 301 estudiantes secundarios, con preguntas sobre relaciones románticas, comportamiento sexual y percepción de riesgo. Se encontró que los adolescentes subestiman su propio riesgo cuando se comparan con otros y cuando consideran la posibilidad de contagio pasado y futuro. El amor no aparece directamente vinculado a la auto-percepción de riesgo, pero, junto con noviazgo, se presenta como factor que complica relaciones sexuales protegidas y relacionado con la subestimación del riesgo de la pareja. Se observó que relaciones estables y amor son elementos que aumentan la vulnerabilidad al VIH, al tener relación con confianza en la pareja y justificar prácticas de riesgo, como no usar condones.
\end{abstract}

Palabras clave: amor, vulnerabilidad, VIH, adolescencia

According to the World Health Organization, infection by HIV is one of the main causes of death among adolescents worldwide (WHO, 2014), although, globally, a reduction in new cases has been observed among people in the age range between 15 and 24 years old (UNAIDS, 2013). In relation to Brazil, the AIDS/STD Epidemiological Bulletin (2010) shows that the highest rates of infection are in the age range between 30 and 49 years old, for both sexes. Considering that

\footnotetext{
1 Correspondence address:

Adriana de Aguiar. Rua Pintor Eduardo Dias, 738, apto 304, Barreiros. CEP 88117-013. São José-SC, Brazil. E-mail: adrianadeaguiar@yahoo.com.br
}

the HIV latency period can be long, it is possible that a large proportion of the contaminations occurred in adolescence.

Adolescence is a stage of the lifecycle involving higher exposure to risks, as it is in this stage that initiation into romantic and sexual relationships normally occurs; and, consequently, insertion in contexts involving higher vulnerability to HIV. Being "with" somebody, considered one of the most common forms of romantic involvement among the young, is often a stage which precedes dating (Camargo, Giacomozzi, Wachelke, \& Aguiar, 2007; Matos, Féres-Carneiro, \& Jablonski, 2005). It is characterized by the lack of commitment among the members, with a variable degree of involvement, which may range from 
simple exchanges of kisses and embraces through to sexual relations. There is space for intimacy but, at the same time, a certain distance is maintained (Matos et al., 2005). On the other hand, dating constitutes the principal context for sexual relations (Camargo \& Botelho, 2007; Giacomozzi \& Camargo, 2011).

The concept of vulnerability (Mann, Tarantola, \& Netter, 1993), which arose during the 1980s, conceives of the HIV epidemic as a multi-determined phenomena, formed by "aspects involving from organic susceptibilities through to how health programs are structured, passing through behavioral, cultural, economic and political aspects" (Ayres, França Júnior, Calazans, \& Saletti-Filho, 1999, p. 117). Mann et al. (1993) define vulnerability as collective (programmatic and social) and individual. The programmatic and social vulnerabilities refer to the programs geared towards the prevention, control and assistance in the context of AIDS and consider the general context of the individuals. Individual vulnerability presupposes that all the individuals, to a greater or lesser degree, are vulnerable to HIV, which will depend on the values and resources which make access to means for protection possible, involving cognitive, behavioral and social aspects. Although all are vulnerable, some may be more directly exposed to the risk than others, and this exposure, besides other elements, is influenced by the evaluation which people make regarding their own chances of infection by HIV, such that the risk perception may be understood as a cognitive aspect involved in the individual vulnerability. Due to the impossibility of addressing the multiple aspects involved in vulnerability in a single study, in this article the use of the term "vulnerability" refers only to some aspects of the individual vulnerability.

Risk perception is defined as how lay persons think about risk, including a set of beliefs and values which give meaning to a threatening occurrence. Thus, in evaluating risk, people include a subjective judgment in which scientific content is associated with psychosocial, cultural and political factors (Slovic, 2006). Social Psychology studies the symbolic dimension of risk, considering its calculation as a social construction. For the perspective of the social amplification of risk (Kasperson et al., 1988), the same is signified through a complex of interactions between different actors in the social structure. The meaning attributed to it will determine the subsequent effects which the risk may have in distinct social contexts, such as, for example, the nature of the actions taken in response; the process of attenuation may result from the connection between risk and its benefits (Breakwell, 2007) and the perception of the risk may present a relationship which is inversely proportional to the perception of its benefits (Slovic, Fischhoff, \& Lichtenstein, 2006).

Various studies have shown that risk in relation to HIV is perceived as a context which is distanced from the individuals (Adefuye, Abiona, Balogun, \& Lukobo-Durrell, 2009; Albuquerque, Moço, \& Batista, 2010; Camargo, Giacomozzi,
Wachelke, \& Aguiar, 2010; Giacomozzi \& Camargo, 2011; Silva \& Vargens, 2009; Sychareun, Thomsen, Chaleunvong, $\&$ Faxelid, 2013). Referring directly to the young, studies indicate that they tend to underestimate their risks of infection by HIV and to overestimate the risks of their peers (Anderson, Beutel, \& Maughan-Brown, 2007; Mwale, 2008). In addition, aspects of peoples' relationships can influence their perceptions of risk in relation to HIV. The study of Kershaw, Ethier, Niccolai, Lewis and Ickovics (2003) identified a relationship between distortion of the perception of risk for HIV and the context of romantic relationships, in which underestimation of the risk was greater among adolescents in longer-lasting relationships. Harman, O'Grady and Wilson (2009) observed that women in long-term relationships evaluated their partners' sexual behaviors of risk inaccurately, and thought them to be similar to their own, underestimating, therefore, the risk of infection by HIV.

Various studies have also found a relationship between the length of the relationship and protective behaviors in relation to HIV, showing that the use of condoms reduces over the course of the relationship (Arraes et al., 2013; Bralock \& Koniak-Griffin, 2009; Garcia \& Souza, 2010; Oltramari \& Camargo, 2010) and is significantly more frequent in casual relationships than in stable ones (Giacomozzi \& Camargo, 2011; Camargo et al., 2010; Garcia \& Souza, 2010; Oliveira, Pontes, Gomes, \& Ribeiro, 2009). The adoption or not of protective conducts in relation to HIV is linked to the evaluation which the person makes in relation to their own exposure to the virus, which also has to do with the perception of the extent to which the partner represents a risk for the occurrence of contagion. In this regard, in addition to the multiple dimensions such as the economic, political and cultural dimensions, vulnerability to HIV is associated with characteristic factors present in the routine of the interpersonal relationships, which guide practices and which can increase individuals' chances of coming to be infected by HIV.

In accordance with the Theory of Social Perception (Heider, 1958), people perceive the context through a lens, in which they take into consideration a variety of processes which mediate how this context is perceived by each person. These mediating psychological processes encompass a series of individual and collective factors, such as the system of beliefs, values, interests, needs, feelings, and attributions of causality, among other social schemes, which act in the symbolic process employed in the representation of the object perceived, and which can contribute to the distortion of the real object. These act by selecting specific aspects of the context to the detriment of others, and this selection explains - in part - some phenomena involved in the process of social interaction, such as, for example, why people tend to perceive negative characteristics in people who they don't like, and positive characteristics in people who they do. In this regard, the perception of the other is shown to be relevant when the contexts related to 
HIV are considered, such as intimate relationships. Love, a feeling present in many of these relationships, can influence the perception which people have of their partners and, consequently, how they interpret the risk, and the exposure itself, in relation to HIV.

The approach to the construct of "love" in this study occurs in the perspective of the Triangular Love Scale (Sternberg, 1986), which understands it as one of the more intense and desirable human emotions, formed by a combination of three components: passion, intimacy and commitment. Together, these components form the vertices of a triangle, and the same can change over the course of different historical and cultural contexts. Passion is defined as a state of intense desire for unity with the other, expressing desires and needs, and which is related to the feeling of giving of oneself and to the sexual dimension. It relates to the units which lead to romance, physical attraction and sexual consummation. It essentially involves a motivational component. Intimacy is the ability to share feelings, and is related with the feeling of trust and approximation, bonds and connection with the other, as well as the existence of respect, understanding, support and communication with the partner. It is a component which is more linked to the emotions. Commitment is the most cognitive component, and is divided in two aspects: short-term and long-term. The first aspect refers to the decision to love the other person, while the second relates to maintenance of this love.

For Sternberg (1986), the components of intimacy and commitment are relatively stable in a romantic relationship, in contrast with the component of passion, which is endowed with a certain instability, and which may come or go with a certain degree of unpredictability. The importance of each one of the three components of love varies, on average, due to the length of the relationship. In short relationships, especially romantic ones, the component of passion tends to perform a major role; that of intimacy may act moderately, and commitment may practically not act at all. In contrast, the two last components are considered the main parts in a longterm relationship. According to Costa and Lima (1998), the component which characterizes each type of love influences how the person perceives their partner: passion leads to the idealization of the other, while intimacy is responsible for the appearance of feelings of trust.

Murray and Holmes (1997) ascertain the existence of a relationship between positive images of the partner and feelings of trust, love and satisfaction with the relationship, the idealization of the partner appearing to be associated with feelings of invulnerability. Bralock and Koniak-Griffin (2009) identified love as one of the rationales for ceasing to use condoms in romantic relationships among adolescents. This being the case, the distinct forms of perceiving and evaluating the relationship and the partner may be reflected in how people perceive their susceptibility in relation to HIV (Costa \& Lima, 1998) and, as a consequence, entail the adoption or not of protective behaviors. As a result, this study investigated the relationship of love and of different romantic relationships with variables of vulnerability to HIV, such as sexual behavior and risk perception. The following hypotheses were constructed: (a) higher levels of love will be related to a lower perception of risk in relation to HIV, (b) higher levels of love will be related to greater underestimation of the risk of the partner, and (c) high levels of love will be related to the greater practice of unprotected sex.

\section{Method}

\section{Participants}

A total of 301 adolescents participated in the study, aged between 15 and 19 years old $(M=16$ years 4 months old; $S D=1$ year 3 months), of both sexes, students in three state senior high schools in Florianópolis in the Brazilian State of Santa Catarina. The age was limited to a minimum of 15 years old, given that initiation of sexual activities occurs predominantly around this age range (Anjos, Silva, Val, Rincon, \& Nichiata, 2012; Camargo et al., 2010). The majority were female $(57.8 \%)$, students in the first year of senior high school (48.2\%), and had a family income of up to three minimum salaries (57.2\%).

\section{Instruments}

A structured questionnaire was used, with closed questions containing: (1) Socio-demographic characteristics, such as sex, age, school year and family income; (2) Characterization of the current romantic relationship: dates/is frequently "with" the same person/ is "with" various persons, with nobody in specific/without a romantic relationship; (3) Duration of the current relationship; (4) Sexual behavior: sexual experience and condom use; (5) Perception of risk in relation to HIV, measured through five items on a scale: (5.1) "In comparison with the Brazilian population in general, what risk do you think you run of being contaminated by HIV?"; (5.2) "In comparison with people of the same age as you, what risk do you think you run of being contaminated by HIV?"; (5.3) "Taking into account the last 12 months, what risk do you think you ran of being infected by HIV?"; (5.4) "How do you evaluate the chance of coming to be contaminated by HIV in the future?"; (5.5) "Thinking about your current partner (or most recent partner, should you not be dating or "with" somebody at the moment), how do you evaluate the chances of this person contracting HIV in the future?". The first two items aimed to evaluate the adolescents' perception of risk when the same compare themselves to other groups, and varied from 1 (much less risk) to 5 (much more risk); the three last, on the other hand, aimed to assess the perception of risk on a temporal perspective (past and future) and, in the case of the last item, the partner's risk, varying from 0 (impossible) to 4 (very possible). 
Also used was the Brazilian reduced version of the Sternberg Triangular Love Scale (TLS) (Cassepp-Borges \& Teodoro, 2007). This instrument aimed to measure the level of love, and was composed of three subscales, corresponding to the three components of love proposed by Sternberg (1986): Passion ("I catch myself thinking of this person various times a day"/"When I watch romantic films or read romantic books, I think about this person"), Intimacy ("I feel that this person really understands me"/“I receive a lot of emotional support from this person") and Commitment ("I hope that my love for this person will last for the rest of my life"/"This person can count on me when they need me"). It is a Likert-type scale, adapted for five points, ranging from 5 (strongly agree) to 1 (strongly disagree), and is made up of 18 items, with six for each component. At the beginning of this, there was a question advising the participants to choose a person who corresponded to the type of the current relationship: (a) girlfriend or boyfriend; or (b) a person with whom he or she was frequently, but whom he or she was not dating; or (c) a person whom he or she had dated or been with in the past (most recent relationship); or (d) an idealized person, who symbolized somebody with whom one would like to have a relationship. The TLS had high internal consistency for the sample analyzed $(\alpha=.93)$.

\section{Procedure}

Data collection. Data collection took place in schools, and the instruments were self-administered in collective situations in the classroom. The participants were advised verbally to respond to the TLS considering the current partner (in the case of those dating or being "with" the same person), the most recent partner (in the case of those with no fixed relationship) or a conjectured person (in the case of those participants who had never had a romantic relationship).

Data analysis. The data were analyzed using descriptive and relational statistics. The relation between the socio-demographic variables, the characterization of the romantic relationships, the length of the relationship and sexual behavior were verified using the association test (Chi-squared). The relationship of these variables with the TLS and with the items of risk perception were verified using the Student $t$ test and ANOVA test. The relationship between the TLS and the perception of risk was verified using Pearson correlations.

\section{Ethical Considerations}

This study complied with the ethical requirements, and was approved by the Universidade Federal de Santa Catarina's Committee for Ethics in Research with Human Beings, under protocol 705/2010. The schools were presented with a research protocol, in accordance with the current ethical precepts, and previous authorization was requested for the undertaking of the study. As the school directors had already received the consent of the students' parents, authorization for the study was obtained following the schools' agreement with the protocol presented.

\section{Results}

More than half of the participants $(58.5 \%)$ stated that they were in a relatively constant romantic relationship with somebody. A higher proportion of the young women mentioned dating $(44.3 \%$ against $22 \%$ of the boys), while casual relationships were more frequent among the boys $\left(33.9 \%\right.$ as against $16.7 \%$ of the girls) $\left[\chi^{2}(3, N=301)=19.9\right.$; $p<.001]$. The length of relationship among those who were dating or were "with" the same person was concentrated in the modalities of 1 to 6 months (37.3\%) and more than one year (37.3\%). Dating was shown to be longer-lasting, as $55.3 \%$ of the participants involved in this type of relationship stated that they had been with their partner for more than one year. On the other hand, among those who were "with" somebody, a high proportion (58.6\%) mentioned more recent relationships, of 1 to 6 months $\left[\chi^{2}(3, N=301)=54.24 ; p<.001\right]$.

The general mean in the TLS was above the mean point of the scale $(M=4.01 ; S D=.70)$. One can observe in Table 1 that the higher scores, both in the TLS as in all its dimensions, were found among those who were dating, while the lower scores were found among those who did not have a fixed relationship. The participants who had longer-lasting relationships also had higher scores on the TLS and in the dimensions of passion and commitment. In the first analysis, the young women had significantly higher scores in the TLS, as well as in the dimensions of passion and commitment. However, in the ANOVA $3 X 2$ with the variables of type of relationship (dating, being "with" a single person, and without a fixed relationship) and sex as independent variables and score in the TLS as the dependent variable, it was ascertained that the differences remain significant in relation to the type of relationship, but not necessarily in relation to $\operatorname{sex}(F(2.295)=1.00 ; p=.37)$. The same happens with the dimensions of passion $(F(2.295)=0.96$; $p=.38)$, intimacy $(F(2.295)=0.68 ; p=.51)$ and commitment $(F(2.295)=0.70 ; p=.50)$.

It was observed that the participants are in a phase of initiation of sexual activities, as a result of which the sample is divided between those who have already experienced sexual relations one or more times $(29.9 \%)$ or many times $(29.3 \%)$ and those who had not yet experienced this (40.8\%). Among those who stated that they had never had sexual relations, a high proportion is among the young women $(67.5 \%)$, while the mode of one or more times is more frequent among the young men $(56.7 \%)\left[\chi^{2}(3, N=301)\right.$ $=12.53 ; p<.01]$. Sexual experiences were shown to be more common among those who were dating $(81.9 \%)$ than among those who were not dating (47\%). The frequency of sexual relations was also greater among the first group. The proportion of those who stated that they had already had many sexual relations is higher among the participants of this group (68.2\%), while the participants who had never had these are concentrated among those who were not dating $(84.5 \%)\left[\chi^{2}(3, N=301)=65.72 ; p<.001\right]$. Among the participants who had already initiated sexual activity, the majority (89.3\%) stated that they had had at least one 
Aguiar, A., \& Camargo, B. V. (2014). Love, Adolescence and Vulnerability to HIV.

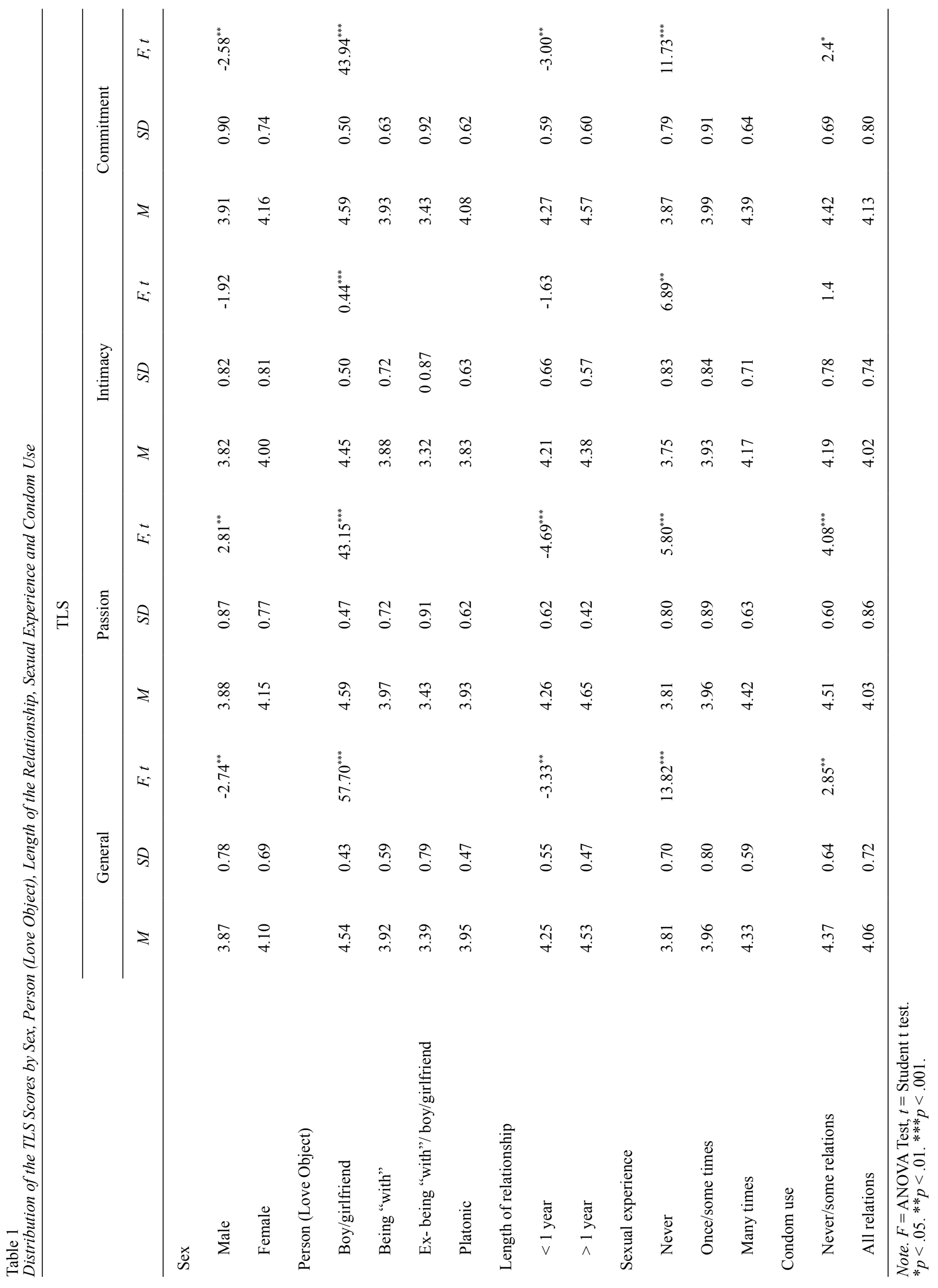


sexual relation in the last 12 months, most of which were practiced with the same person $(70.4 \%)$. Sexual practice with a single partner had the highest proportion among the participants who stated that they were in a relationship with a single person at the time of the study: $83.7 \%$ among those who were dating and $48.6 \%$, among those who were "with" the same person, as against $40 \%$ among those who were "with" various people $\left[\chi^{2}(4, n=178)=33.09 ; p<.001\right]$.

In relation to protective conduct in relation to HIV, more than half of the participants who had sexual relations in the last 12 months stated that they had used condoms in the sexual relations (54.1\%). There were no statistically significant differences in relation to sex, although there were in relation to the condition of dating, such that the systematic use of condoms was lower among those who were dating than among those who were not dating $(39.3 \%$ as against $70.6 \%)\left[\chi^{2}(4, n=159)=16.69\right.$; $p<.01]$; and length of the relationship, as $66 \%$ of the participants in relationships of up to one year referred to the consistent use of condoms, as against $29.1 \%$ of the participants who were in relationships of over one year's duration $\left[\chi^{2}(2, n=108)=14.78 ; p<.01\right]$. requesting condom use $(51.8 \%$ as against $74.7 \%)$ and $\mathrm{HIV}$ (56.6\% as against $72.4 \%$ ). The differences were significant both for the first reason $\left[\chi^{2}(1, N=301)=13.40 ; p<.001\right]$, and for the second $\left[\chi^{2}(1, N=301)=6.37 ; p<.05\right]$.

In comparing their chances of infection by HIV with that of other groups, it was observed that the adolescents had a tendency to underestimate, both when they compared their risk of infection with the risk run by the Brazilian population in general $(M=2.49 ; S D=0.99)$, and when they compared their own risk with that run by persons of the same age $(M=2.56 ; S D=1.07)$. When they compared themselves with the Brazilian population in general, the female adolescents had greater underestimates than the male adolescents, as did the adolescents who were dating when compared with those who were not dating. No statistically significant correlation was observed with the score in the TLS, but a weak negative correlation was observed with the dimension of intimacy when the comparison with the Brazilian population was considered.

In relation to the participants' evaluation in relation to the risk which they had run in the last 12 months, the mean score presented points to a perception which is close to 'impossible' $(M=0.37 ; S D=0.83)$. As may be observed in

\section{Reasons for requesting condom use}

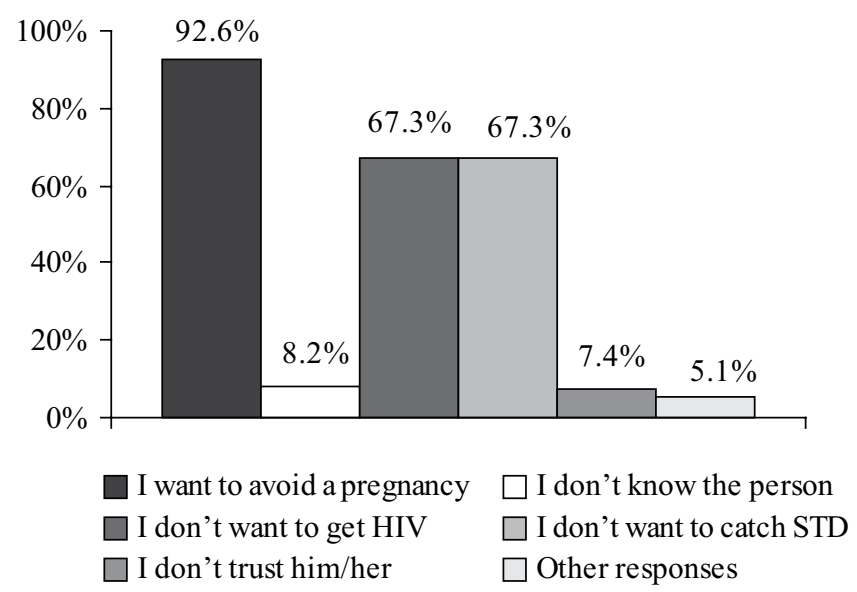

\section{Reasons for not requesting condom use}

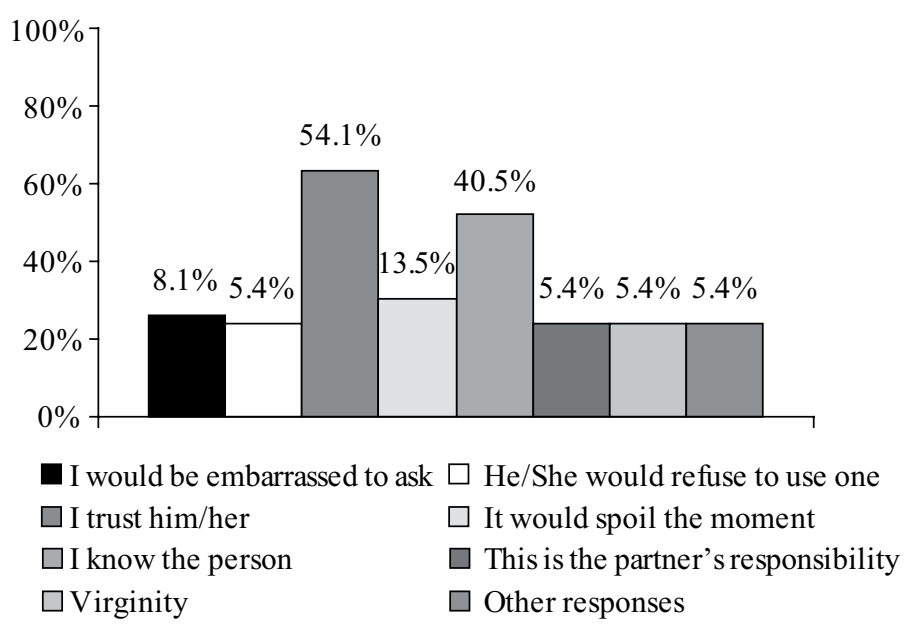

Figure 1. Reasons stated for requesting or not the partner to use a condom. The participants could respond with more than one option.

One can observe in Figure 1 that the participants' main preoccupation is unwanted pregnancy, given that avoiding it appears as the main motive for asking the partner to use condoms in sexual relations, followed by concerns about sexually-transmitted diseases (STD), among them HIV. In contrast, the trust in the partner and knowing the person appear as the main reasons for not requesting condom use. When the reasons in relation to the condition of dating or not dating were combined, it was observed that a smaller proportion of participants who were dating mentioned concerns about avoiding contracting STD as a reason for
Table 2, although one can observe a general underestimate in relation to the risk run in the last 12 months, the participants who stated that they had had sexual relations several times underestimated the probability of having been infected in the last year to a lesser degree than participants with little or no sexual experience. In relation to condom use, it may be observed that the participants who practiced unprotected sex tended to underestimate the risk to a lesser degree than those who used condoms in all their relations, although the level of statistical significance in relation to this difference was marginal. 
Aguiar, A., \& Camargo, B. V. (2014). Love, Adolescence and Vulnerability to HIV.

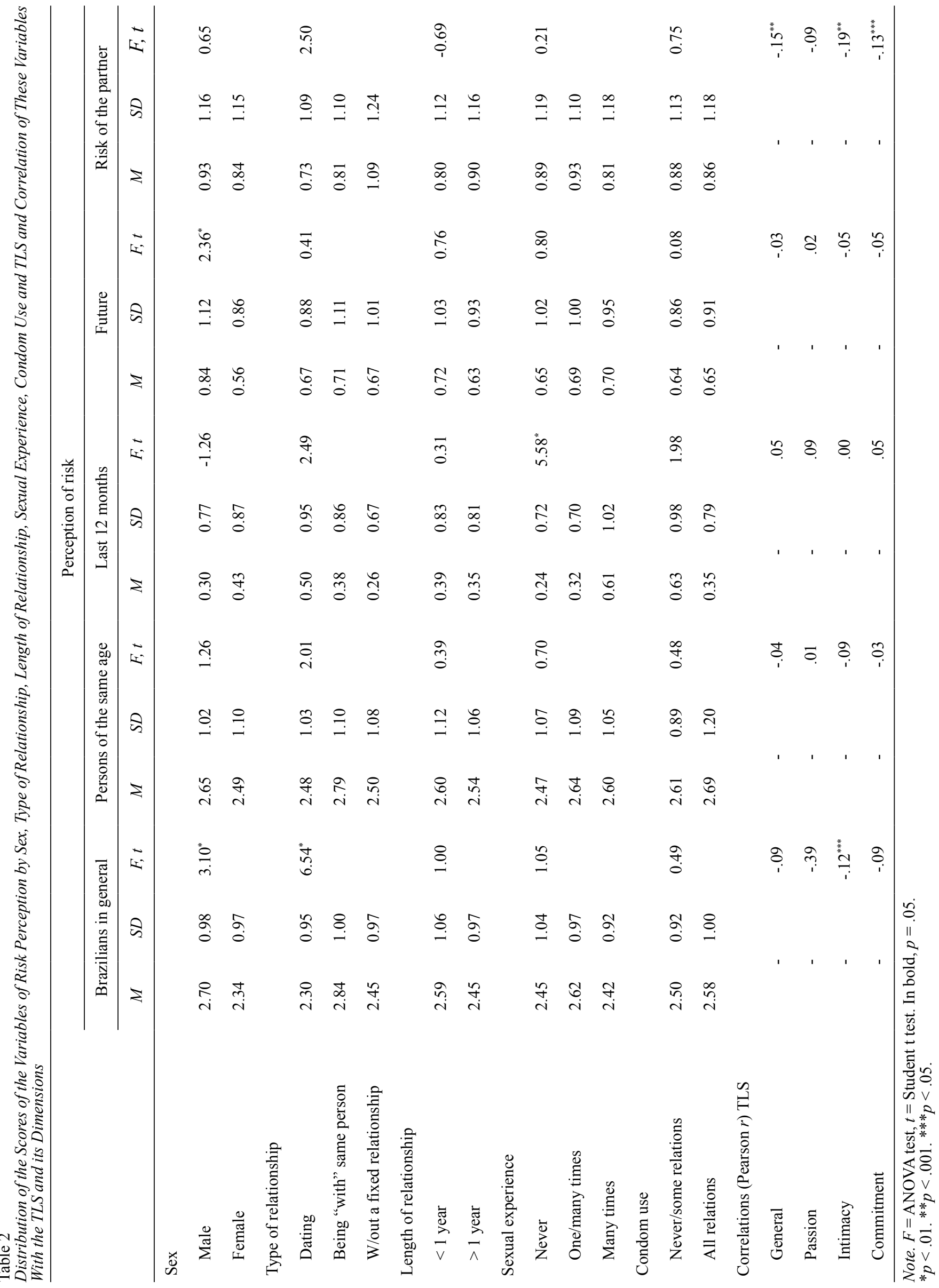


In relation to the evaluation regarding possible future infection by HIV, the adolescents, generally speaking, evaluated their chances as close to 'impossible' $(M=0.68$; $S D=0.99$ ). In relation to sex, as may be observed in Table 2 , the female adolescents made greater underestimates than the males. In relation to the evaluation of the risk of the partner/ex-partner in relation to HIV, it was observed that the participants also showed that they underestimated it $(M=0.87 ; S D=1.15)$. Although a significant difference was not found in relation to the type of relationship, there was a small negative correlation with score in the TLS and in the dimensions of commitment and intimacy.

\section{Discussion}

This study identified differences in relation to gender regarding involvement in romantic relationships, as the adolescent girls tend to be more involved in stable relationships, while the adolescent boys tend to be more involved in casual relationships, corroborating other studies (Giacomozzi \& Camargo, 2011). In general, the level of love presented by the adolescents was high, possibly due to the fact that the same are in a phase naturally characterized by romanticism, which occurs as a result of their starting in romantic relationships and because of the influence of advertisements directed at this public. The adolescent girls' higher means, principally in relation to the dimensions of passion and commitment, may be explained by the greater involvement of the same in relationships of dating, as well as a greater cultural influence in relation to elements linked to romanticism. As expected, higher means were also observed in the TLS among those who were dating, possibly due to this form of relationship being shown to be longerlasting, with emphasis on the presence of the components of intimacy and commitment (Sternberg, 1986). It should be noted that, in this study, intimacy did not appear as a component with a tendency to increase the duration of the relationship, possibly because of this component of love not being exclusive to romantic relationships (Sternberg, 1986), it also being present in relationships of friendship, these often preceding romantic relationships among the young.

In terms of sexual experience, it was observed that more than half of the participants had already initiated sexual activities, and that the male adolescents reported greater sexual experience than the females, as also found by Natividade and Camargo (2011). As in other studies (Camargo \& Botelho, 2007; Giacomozzi \& Camargo, 2011), dating was shown to be the principal context for sexual relations, principally among the female participants. This data indicates that, although involvement in casual relationships may be common among adolescents, sex tends to occur in contexts in which there is continuous affective involvement, viewed with greater formality, commitment and official status before the social group and the family.

In relation to the protective measures against HIV, for a large proportion of the adolescents, condom use was presented as an important preventive instrument, although its use, principally among those who were dating, was linked to a contraceptive strategy rather than as a barrier against HIV and other STD. As a result, the adolescents studied seem to be more concerned with situations which involve immediate consequences, such as a child, than with situations with longterm consequences, as is the case with AIDS. In this regard, dating was shown to be an important variable associated with unprotected sex, this data also being found in other studies (Camargo et al., 2010; Camargo \& Botelho, 2007).

In conjunction with dating, love appeared as a complicating factor for the adoption of protective measures, as condom use was lower among adolescents who presented higher scores in the TLS. These differences were observed mainly in relation to passion and commitment, such that having unprotected sex appeared to be related mainly to those adolescents who were more impassioned and presented higher levels of commitment to the partners, two important elements present in stable relationships. As passion is defined as a more motivational feeling, linked to the intensity of the desire for the other, and commitment is defined as a dimension related to the stability of the relationship (Sternberg, 1986), these results indicate that unprotected sex may be related, on the one hand, to a more impulsive condition, more linked to the moment, or, on the other, to a more rational condition, through the option not to use condoms over the course of the relationship, often explained by the establishment of the feeling of trust in the partner. This being the case, passion, as the component responsible for the idealization of the partner, and commitment, as a fundamental component in supporting the romantic relationships, appear in these contexts as barriers against the virus, corroborating studies with other populations, in which love was considered a protection against HIV (Bralock \& Koniak-Griffin, 2009; Manuel, 2009).

In addition, it was observed that there is an increase in sexual relations and a gradual cessation of condom use over the course of the relationships, suggesting that the concern with STD is restricted to the beginning of the relationship, reducing significantly as familiarity with the partner increases, which has also been found in other studies (Arraes et al., 2013; Garcia \& Souza, 2010; Oliveira et al., 2009; Oltramari $\&$ Camargo, 2010). In this regard, there is a minimum time period considered necessary for the knowledge of the partner and the establishment of a relationship of trust, in which condoms may be dispensed with in favor of the contraceptive pill. However, in adolescence, as a result of the high turnover of partners, this familiarity is established in a short period of time, which does not always allow the partners' current or past behaviors of risk to be known totally. Furthermore, the romantic atmosphere, which is characteristic of relationships in adolescence, with emphasis on passion, leads to a rapid idealization of the partner. For Costa and Lima (1998), the affective idealization of the partner is responsible for the satisfaction with the relationship and results in the attribution of desirable virtues to the other, contributing to the development of the feeling of trust. 
In relation to the perception of risk, significant differences were observed between those adolescents who were dating and those who were not, in that adolescents who were dating felt safer than the adolescents in other types of relationships when they compared their own risk with that run by the Brazilian population in general. The lower perception of risk among those who were dating may be explained by the trust, as this appeared in studies with other populations, associated with feelings of invulnerability (Albuquerque et al. 2010; Oltramari \& Camargo, 2010). It was also observed that the adolescents underestimate their own risk in comparison with their peers, indicating that AIDS is seen as a disease of the other, a possibility projected in the exterior world, as found in other studies (Anderson et al., 2007; Camargo et al., 2010; Mwale, 2008).

Considering time, the participants also showed that they underestimated the risk, as they evaluated as nearly impossible both the possibility of having been infected by HIV in the last 12 months and the possibility of coming to be infected in the future. The feeling of invulnerability among adolescents has also been identified in other studies (Arraes et al., 2013; Bralock \& Koniak-Griffin, 2009; Sychareun et al., 2013). The male adolescents evaluated that they had a higher chance of being infected in the future, probably due to their greater involvement in casual relationships in comparison with the female adolescents.

Love was shown to be more correlated with the item measuring indirect perception of the risk. The score in the TLS and the perception of risk of the partner were correlated negatively, demonstrating that the partners with high levels of love tended to underestimate more their partners' risk of infection with HIV. In this scenario, intimacy and commitment appear as the principal elements guiding this evaluation. These two components of love perform an important role in long-term affective bonds, this being one of the elements responsible for the maintenance of, and satisfaction with, the relationship (Sternberg, 1986). The study of Kershaw et al. (2003) strengthens this link, as it identified feelings of invulnerability associated with longer-lasting relationships, as did Costa and Lima (1998), which also found a relation between commitment and feelings of invulnerability in relation to HIV. However, in this last study, the authors did not observe the direct relation between love and the perception of risk; they observed that love exercises a direct effect on optimism in relation to the partner's risk, this being, therefore, indirectly linked to a greater risk in relation to HIV. In the evaluation of the risk, the adolescents do not take into consideration only statistical probabilities, but link it to the meaning of the risk elements which are endowed with importance in their daily lives, mainly those involved in romantic relationships, as is the case with trust, itself a subproduct of love.

\section{Conclusion}

This study's results show that the adolescents studied are vulnerable to HIV because they underestimate their risk in comparison with other groups of individuals, due to denying that their partners represent a risk, and due to inconsistent condom use. Love appears as a variable associated with the adolescents' greater vulnerability due to being related mainly with the increase in sexual experience, underestimation of the risk from the partner, and greater practice of unprotected sex.

Risky behaviors for HIV also appear to be associated with the experience of dating. The meaning of the condom may be shown to be linked to the idea of mistrust and diseases, therefore, the same, as a protective measure, has no place in sexual relations immersed in an affective context in which love is culturally attributed and socially valued. This representation may be reinforced by some characteristics present in the preventive campaigns, which are intensified at certain times of the year, such as that of Carnival - a period associated in Brazil with casual sex and multiple partners. One suggestion could be that these campaigns should be intensified in other periods of the year, associated with dates in which love and affective bonds are extolled, such as Valentine's Day.

This study contributed to a better grasp of the emotional aspects which increase vulnerability to HIV; these aspects need to be considered in the development of public policies and preventive interventions directed at adolescents. As a result, it is an advance, in the extent to which it fills a gap in the literature, given that the majority of Brazilian studies found, although addressing romantic relationships, do not specifically investigate love as an element complicating the prevention of HIV among adolescents.

The methodological strategy adopted in this study was shown to be an important limitation, as the abstract and multidimensional nature of love makes it difficult to measure using only an objective measurement, leading to a result which can only be partial. Moreover, the data obtained cannot be generalized, as the study was undertaken in only one city, and only with students from state schools. In this regard, further studies are necessary to deepen knowledge of the multidimensional aspects of love and their relationship with vulnerability to HIV, making use of other methodological strategies, as well as samples from other regions of the country and from different socio-economic levels.

\section{References}

Adefuye, A. S., Abiona, T. C., Balogun, J. A., \& LukoboDurrell, M. (2009). HIV sexual risk behaviors and perception of risk among college students: Implications for planning interventions. BMC Public Health, 9, 281. doi:10.1186/1471-2458-9-281

Albuquerque, V. S., Moço, E. T. -S. M., \& Batista, C. S. (2010). Mulheres negras e HIV: Determinantes de vulnerabilidade na região serrana do estado do Rio de Janeiro. Saúde e Sociedade, 19(Supl.2), 63-74. doi:10.1590/S0104-12902010000600007 
Anderson, K. G., Beutel, A. M., \& Maughan-Brown, B. (2007). HIV risk perceptions and first sexual intercourse among youth in Cape Town South Africa. International Family Planning Perspectives, 33(3), 98-105.

Anjos, R. H. D., Silva, J. A. S., Val, L. F., Rincon, L. A., \& Nichiata, L. Y. I. (2012). Diferenças entre adolescentes do sexo feminino e masculino na vulnerabilidade individual ao HIV. Revista da Escola de Enfermagem da USP, 46(4), 829-836. doi:10.1590/S008062342012000400007

Arraes, C. O., Palos, M. A. P., Barbosa, M. A., Teles, S. A., Souza, M. M., \& Matos, M. A. (2013). Masculinidade, vulnerabilidade e prevenção relacionadas às doenças sexualmente transmissíveis/HIV/Aids entre adolescentes do sexo masculino: Representações sociais em assentamento da reforma agrária. Revista Latino-Americana de Enfermagem, 21(6), 1266-1273. doi:10.1590/0104-1169.3059.2363

Ayres, J. R. C. M., França Júnior, I., Calazans, G. J., \& Saletti Filho, H. C. (1999). Vulnerabilidade e prevenção em tempos de Aids. In R. M. Barbosa \& R. Parker (Orgs.), Sexualidades pelo avesso: Direitos, identidades e poder (pp. 49-72). São Paulo, SP: 34.

Boletim Epidemiológico AIDS/DST. (2010). Retrieved from http:/www.aids.gov.br/sites/default/files/anexos/ publicacao/2010/45974/vers_o_final_15923.pdf

Bralock, A., \& Koniak-Griffin, D. (2009). What do sexually active adolescent females say about relationship issues? Journal of Pediatric Nursing, 24(2), 131-140. doi:10.1016/j.pedn.2008.02.036

Breakwell, G. M. (2007). Social amplification and social representations of risk. In The psychology of risk (pp. 224265).Cambridge, England: Cambridge University Press.

Camargo, B. V., \& Botelho, L. J. (2007). Aids, sexualidade e atitudes de adolescentes sobre proteção contra o HIV. Revista de Saúde Pública, 41(1), 61-68. doi:10.1590/S003489102006005000013

Camargo, B. V., Giacomozzi, A. I., Wachelke, J. F. R., \& Aguiar, A. (2007). Estudo exploratório sobre etnia $e$ vulnerabilidade frente a AIDS. Paper presented at the fifth Jornada Internacional and the third Conferência Brasileira sobre Representações Sociais, Brasília, DF.

Camargo, B. V., Giacomozzi, A. I., Wachelke, J. F. R., \& Aguiar, A. (2010). Relações amorosas, comportamento sexual e vulnerabilidade de adolescentes afrodescendentes e brancos em relação ao HIV/Aids. Saúde e Sociedade, 19(Supl. 2), 36-50. doi:10.1590/S0104-12902010000600005

Cassepp-Borges, V., \& Teodoro, M. L. M. (2007). Propriedades psicométricas da escala triangular do amor de Sternberg. Psicologia: Reflexão e Crítica, 20(3), 513-522. doi:10.1590/S010279722007000300020

Costa, C., \& Lima, M. L. (1998). O papel do amor na percepção de invulnerabilidade à Sida. Psicologia, 12(1), 41-62.

Garcia, S., \& Souza, F. M. (2010). Vulnerabilidades ao HIV/Aids no contexto brasileiro: Iniquidades de gênero, raça e geração. Saúde e Sociedade, 19(Supl. 2), 9-20. doi:10.1590/S0104-12902010000600003
Giacomozzi, A. I., \& Camargo, B. V. (2011). Vulnerabilidade de adolescentes afrodescendentes e caucasianos em relação ao HIV/SIDA. Psicologia, Saúde \& Doenças, 12(1), 143-160.

Harman, J. J., O’Grady, M. A., \& Wilson, K. (2009). What you think you know can hurt you: Perceptual biases about HIV risk in intimate relationships. AIDS Behavior, 13(2), 246-257. doi:10.1007/s10461-007-9341-5

Heider, F. (1958). Psicologia das relações interpessoais (D. M. Leite, Trad.). São Paulo, SP: Pioneira/EDUSP.

Kasperson, R. E., Renn, O., Slovic, P., Brown, H. S., Emel, J., Goble, R., ... Ratick, S. (1988). The social amplification of risk: Aconceptual framework. RiskAnalysis, 8(2), 177-187. doi:10.1111/j.1539-6924.1988.tb01168.x

Kershaw, T. S., Ethier, K. A., Niccolai, L. M., Lewis, J. B., \& Ickovics, J. R. (2003). Misperceived risk among female adolescents: Social and psychological factors associated with sexual risk accuracy. Health Psychology, 22(5), 523-532. doi:10.1037/0278-6133.22.5.523

Mann, J., Tarantola, D. J. M., \& Netter, T. W. (1993). A Aids no mundo (Outras Palavras, Trad.). Rio de Janeiro: RelumeDumará/BIA/IMS/UERJ.

Manuel, S. (2009). Presentes perigosos: Dinâmicas de risco de infecção ao HIV/Aids nos relacionamentos de namoro em Maputo. Physis: Revista de Saúde Coletiva, 19(2), 371-386. doi:10.1590/S010373312009000200007

Matos, M., Féres-Carneiro, T., \& Jablonski, B. (2005). Adolescência e relações amorosas: Um estudo sobre jovens das camadas populares cariocas. Interação em Psicologia, 9(1), 21-33.

Murray, S. L., \& Holmes, J. G. (1997). A Leap of Faith? Positive illusions in romantic relationships. Personality and Social Psychology Bulletin, 23(6), 586-604. doi:10.1177/0146167297236003

Mwale, M. (2008). Adolescent risk-perception cognition and self-assessment in relation to the HIV/AIDS pandemic: The case of some selected schools in Zomba, Malawi. Psychology and Developing Societies, 20(2), 229-240. doi:10.1177/097133360802000205

Natividade, J. C., \& Camargo, B. V. (2011). Representações sociais, conhecimento científico e fontes de informação sobre aids. Paidéia (Ribeirão Preto), 21(49), 165-174. doi:10.1590/S0103-863X2011000200004

Oliveira, D. C., Pontes, A. P. M., Gomes, A. M. T., \& Ribeiro, M. C. M. (2009). Conhecimentos e práticas de adolescentes acerca das DST/HIV/AIDS em duas escolas públicas municipais do Rio de Janeiro. Escola Anna Nery, 13(4), 833-841. doi:10.1590/S1414-81452009000400020

Oltramari, L. C., \& Camargo, B. V. (2010). AIDS, relações conjugais e confiança: Um estudo sobre representações sociais. Psicologia em Estudo, 15(2), 275-283. doi:10.1590/S1413-73722010000200006

Silva, C. M., \& Vargens, O. M. C. (2009). A percepção de mulheres quanto à vulnerabilidade feminina para contrair DST/HIV. Revista da Escola de enfermagem da USP, 43(2),401-406. doi:10.1590/S0080-62342009000200020 
Slovic, P. (2006). Perception of risk. In The perception of risk (pp. 220-232). London, England: EarthScan.

Slovic, P., Fischhoff, B., \& Lichtenstein, S. (2006). Facts and fears: Understanding perceived risk. In The perception of risk (pp. 136-153). London, England: EarthScan.

Sternberg, R. J. (1986). A triangular theory of love. Psychological Review, 93(2), 119-135. doi:10.1037/0033 295X.93.2.119

Sychareun, V., Thomsen, S., Chaleunvong, K., \& Faxelid, E. (2013). Risk perceptions of STIs/HIV and sexual risk behaviors among sexually experienced adolescents in the Northern part of Lao PDR. BMC Public Health, 13, 1126. doi:10.1186/1471-2458-13-1126

UNAIDS (2013): HIV, adolescents and youth. Geneva, Switzerland: WHO. Retrieved from: http://www. unaids.org/en/media/unaids/contentassets/documents/ pcb/2013/pcb33/agendaitems/20131121_Thematicsegment-HIV-\%20youth-adolescents\%20.pdf

World Health Organization (2014). Maternal, newborn, child and adolescent health. Geneva, Switzerland: WHO. Retrieved from: http://www.who.int/maternal_child_ adolescent/epidemiology/adolescence/en/

Adriana de Aguiar is a Ph.D. candidate in the Graduate Program in Psychology at the Universidade Federal de Santa Catarina.

Brigido Vizeu Camargo is an Associate Professor of the Universidade Federal de Santa Catarina.

Received: Nov. 12, 2012

1st Revision: June 10, 2014

Approved: July 21, 2014

How to cite this article:

Aguiar, A., \& Camargo, B. V. (2014). Romantic relationships, adolescence and HIV: Love as an element of vulnerability. Paidéia (Ribeirão Preto), 24(58), 165-175. doi: 10.1590/1982-43272458201404 


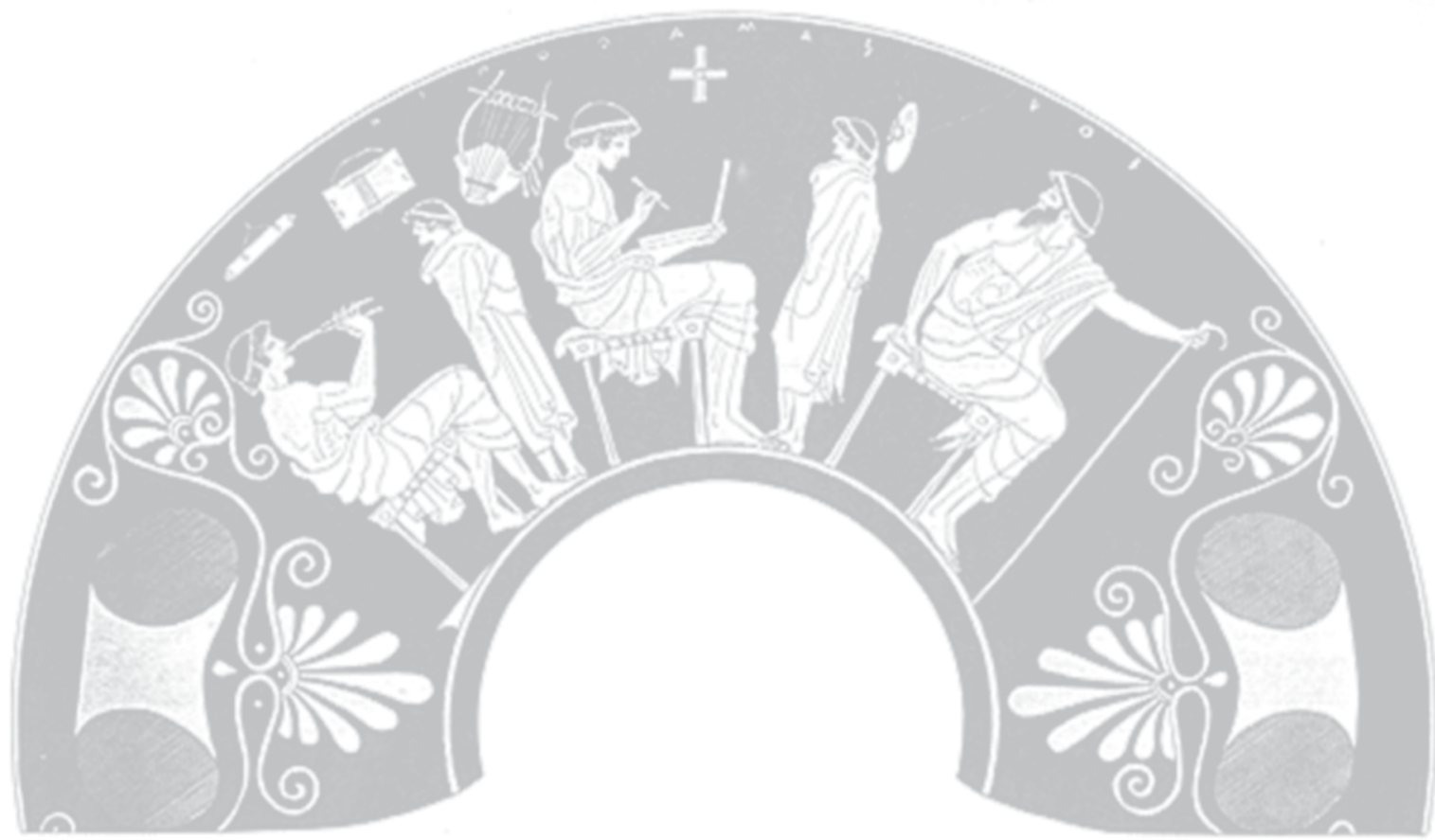

